\title{
Maternal serum CA-125 repeated measurement during pregnancy and how to use as a prognostic factor of first trimester pregnancy outcome
}

\author{
Nasreen S. Badr ${ }^{1 *}$, Samira Y. El Mallah¹, Magda I. El Mahdy ${ }^{2}$, Hanaa F. Ahmad ${ }^{1}$
}

\begin{abstract}
${ }^{1}$ Department of Obstetrics and Gynecology, ${ }^{2}$ Department of Clinical Pathology, Al-Azhar University Faculty of Medicine for Girls. Cairo, Egypt
\end{abstract}

Received: 23 November 2021

Revised: 12 December 2021

Accepted: 13 December 2021

*Correspondence:

Dr. Nasreen S. Badr,

E-mail: drnesreen_sameer@yahoo.com

Copyright: ( $)$ the author(s), publisher and licensee Medip Academy. This is an open-access article distributed under the terms of the Creative Commons Attribution Non-Commercial License, which permits unrestricted non-commercial use, distribution, and reproduction in any medium, provided the original work is properly cited.

\section{ABSTRACT}

Background: The aim of this study was to estimate the prognostic efficacy of repeated measurement of maternal serum CA125 in first trimester threatened miscarriage.

Methods: Prospective case control study was conducted in the outpatient clinic. 100 pregnant women were divided into 50 women with normal course of pregnancy, and the other 50 were subdivided into 25 pregnant women with lower abdominal pain without vaginal bleeding and 25 presented with minimal vaginal bleeding. Repeated measuring of serum CA125 was done for each case on the $5^{\text {th }}, 10^{\text {th }}$ weeks of gestation.

Results: Findings of this study suggested the possibility of using serum CA- 125 for determining the prognosis of first trimester threatened miscarriage with cut-off value of CA125 $38.25 \mathrm{U} / \mathrm{ml}$ on the $5^{\text {th }}$ week of gestation and $53 \mathrm{U} / \mathrm{ml}$ on the $10^{\text {th }}$ week of gestation in patients presented with pain only but in patients presented with minimal vaginal bleeding the cut-off value of CA125 on the $5^{\text {th }}$ week of gestation become $45.6 \mathrm{U} / \mathrm{ml}$ and $68 \mathrm{U} / \mathrm{ml}$ on the $10^{\text {th }}$ week of gestation. Conclusions: CA125, on its own, can discriminate between continued and non-continued pregnancy.

Keywords: CA125, Pregnancy, Threatened miscarriage

\section{INTRODUCTION}

The CA-125 tumor marker is a cell-surface antigen derived from the surface coelomic epithelium, including the mucosa of the entire female genital tract and the germinal epithelium of the ovaries. The fetal chorion, amniotic fluid, and maternal decidua also have been shown to contain significant amounts of CA-125 protein, and represent potential sources of the elevated serum levels of the protein in pregnancy. ${ }^{1}$

High levels of serum CA-125 was noticed in patients with normal early pregnancy, spontaneous abortion, and hydatiform mole; but the levels were low in patients with tubal pregnancy, especially if there had been no uterine bleeding. ${ }^{2}$
Schmidt et al concluded that single serum measurements of CA-125 in symptomatic first trimester pregnancies failed to discriminate between spontaneous abortion, ectopic, and normal pregnancies; however recent study done by Yadav et al concluded that single raised maternal serum CA-125 value has best predictive value., ${ }^{3,4}$

Nevertheless, some studies have shown that serum CA125 measurements failed to discriminate between EP, and normal pregnancy.

Therefore, we assessed the possibility of using maternal CA125 alone in one measurement and also in repeated measurements as a prognostic factor of early pregnancy miscarriage. 


\section{METHODS}

This prospective case control study was conducted in outpatient clinic at Al Zahraa University Hospital and was done in the period between October 2018 and December 2019.

Firstly, the study was conducted on 115 pregnant women in the outpatient clinic but 15 of them didn't attend at the $10^{\text {th }}$ week of gestation so the end results were 100 pregnant women divided into: group I (control group): 50 pregnant women with normal course of pregnancy. Group II (cases group): 50 pregnant women subdivided into: group IIa: 25 pregnant women with lower abdominal pain without vaginal bleeding group IIb: and 25 presented with minimal vaginal bleeding. The groups were examined at $5^{\text {th }}$ and $10^{\text {th }}$ week of gestation and followed up till $12^{\text {th }}$ week of gestation.

\section{Inclusion criteria}

Intact single intrauterine gestational sacs were included in this study. Pregnant woman presented with threatened miscarriage in the form of recurrent attacks of minimal vaginal bleeding or lower abdominal pain.

\section{Exclusion criteria}

Any uterine vaginal or cervical lesion that could explain the vaginal bleeding; multiple pregnancy; general causes of bleeding; any cause could affect CA-152 level in blood such as: endometriosis, uterine fibroids (benign tumors), pancreatitis, pelvic inflammatory disease, cirrhosis of the liver, benign and malignant ovarian cysts; additionally malignancies of the uterine tubes, endometrium, lung, breast, pancreas, gastrointestinal tract and lymphoma were also excluded.

Informed consent after explanation was obtained from every pregnant woman. Detailed history was taken then general, abdominal and vaginal examination were done. Blood sample was collected from every case for measuring the serum CA-125 level as follows: the patient needed not to be fasting and no special preparation was necessary. Five $\mathrm{ml}$ of blood were collected from a peripheral vein by venipuncture avoiding hemolysis into plain tubes (without anticoagulant). After clotting of the blood sample, the serum was separated from the cells by centrifugation within 2 hours from collection. The serum was separated and transferred to clean tubes by sterile pipette. A ticket with the patient name and number was placed on each tube. All samples were stored refrigerated at $2-8^{\circ} \mathrm{C}$ for 2 days or for 12 months at $-20^{\circ} \mathrm{C}$. Before assay, the sera were allowed to come to room temperature $\left(15-28^{\circ} \mathrm{C}\right)$ and mixed by gentle swirling or inversion. Serum CA-125 concentrations were measured using the CanAg CA-125 ELISA assay (Fujirebio Diagnostics, Göteborg, Sweden). It is solid-phase, non-competitive immunoassay, based on the direct sandwich technique, and were run according to manufacturer's instructions. The appropriate controls were within the ranges provided by the manufacturer for all runs. Each pregnant woman contact data including mobile number and address were documented and informed if any complication occurred, follow up was done in the out patient's clinic to determine whether bleeding has stopped or continued. Specific date was scheduled to repeat TVUS examination for each case at $10^{\text {th }}$ week of gestation. At $12^{\text {th }}$ week of gestation each woman studied was seen to reevaluate and record if miscarriage happened or continued her pregnancy. The aborted cases below $10^{\text {th }}$ week of gestation were not included in the study.

The data were collected in one hundred files. Each file contains pregnant woman history, report of first ultrasound scan at $5^{\text {th }}$ week of gestation and $10^{\text {th }}$ week then finally twelfth week scan in normal pregnancy or the exact gestational age at which abortion happened.

\section{Statistical analysis}

Data were collected, revised, coded and entered to the Statistical Package for Social Science (IBM SPSS) version 20. Qualitative data were presented as number and percentages while quantitative data with parametric distribution were presented as mean, standard deviations and ranges. The comparison between two groups with qualitative data were done by using Chi-square test and/or Fisher exact test was used instead of Chi-square test when the expected count in any cell was found less than 5 . The comparison between two independent groups regarding quantitative data with parametric distribution was done by using Independent t-test while comparison between two paired groups with parametric distribution was done by using paired t-test. The comparison between more than two independent groups regarding quantitative data with parametric distribution was done by using one way analysis of variance (ANOVA). Receiver operating characteristic curve (ROC) was used to assess the best cut off point with its area under the curve (AUC), sensitivity, specificity, positive predictive value (PPV) and negative predictive value (NPV).

The confidence interval was set to $95 \%$ and the margin of error accepted was set to $5 \%$. So, the $\mathrm{p}$ value was considered significant as the following: $p>0.05$ : nonsignificant, $\mathrm{p}<0.05$ : significant and $\mathrm{p}<0.01$ : highly significant.

\section{RESULTS}

Percentage of abortion in Group IIb was $32 \%$ which is the highest in comparison with group IIa $20 \%$ and in group I was only $8 \%$ (Figures 1, 2, 3).

Highly statistically significant difference between CA-125 level in completed and aborted cases in group I at $5^{\text {th }}$ and $10^{\text {th }}$ week of gestation (Table 1). Also, there was highly statistically significant difference between CA-125 level in completed and aborted cases in group IIa at $5^{\text {th }}$ and $10^{\text {th }}$ week of gestation (Table 2). 


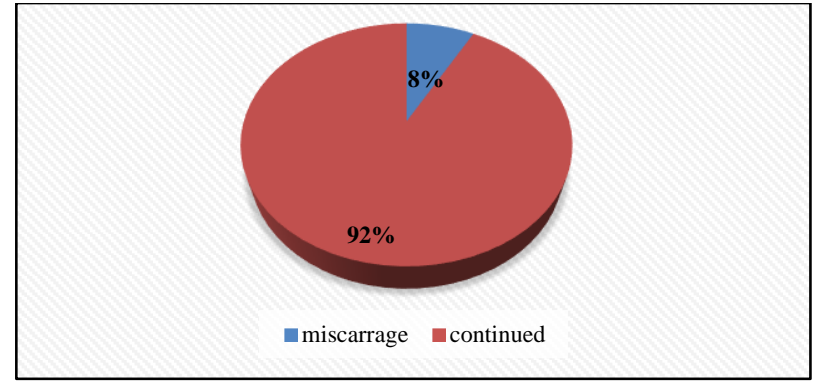

Figure 1: Percentage of miscarriage in group I (control group).

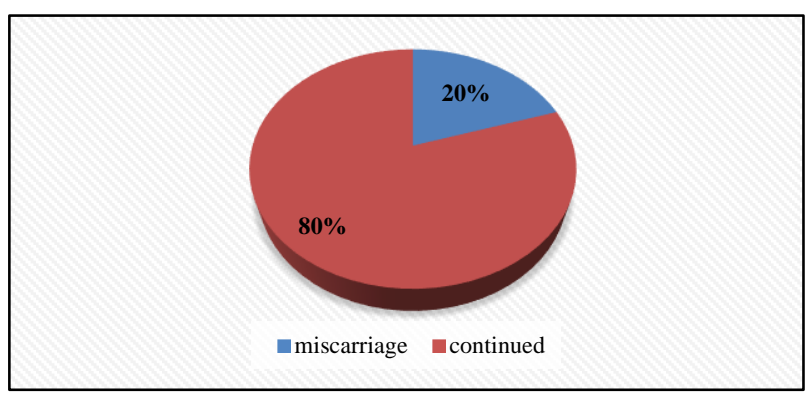

Figure 2: Percentage of miscarriage in group IIa.

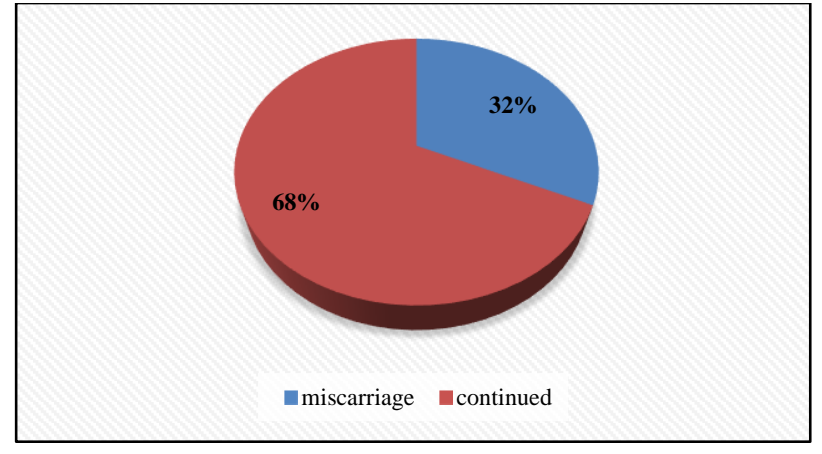

Figure 3: Percentage of miscarriage in group IIb.

The results of the ROC curve analysis demonstrate the high prognostic value of CA-125 at $5^{\text {th }}$ week of gestation for pregnancy failure in group II a with a cut-off value of (38.25 U/ml) (Table 3) and at 10th week of gestation the highest sensitivity and specificity values of $100.00 \%$ were obtained with a cut-off value of $53 \mathrm{U} / \mathrm{ml}$ (Table 4).

There was highly statistically significant difference between CA125 level in completed and aborted cases in group IIb as well (Table 5).

Table 1: Comparison of gestational sac, yolk sac diameter $(\mathrm{mm})$, fetal heart rate $(\mathrm{b} / \mathrm{m})$, crown rump length (mm) and CA-125 $(\mathrm{U} / \mathrm{ml})$ in the women studied at $5^{\text {th }}$ and $10^{\text {th }}$ week of gestation.

\begin{tabular}{|lllllll|}
\hline \multirow{2}{*}{ Total number $(\mathbf{1 0 0})$} & Group I $(\mathbf{n = 5 0})$ & Group Ia $(\mathbf{n = 2 5})$ & Group Ilb $(\mathbf{n = 2 5})$ & \multicolumn{2}{c|}{ One way ANOVA } \\
\cline { 2 - 8 } & Mean \pm SD & Mean \pm SD & Mean \pm SD & F & P value \\
\hline \multirow{2}{*}{ CA125 $(\mathbf{U} / \mathbf{m l})$} & At $5^{\text {th }}$ week & $16.29 \pm 12.24$ & $17.96 \pm 10.69$ & $26.84 \pm 18.02$ & 7.495 & 0.024 \\
\cline { 2 - 9 } & At $10^{\text {th }}$ week & $23.23 \pm 16.58$ & $28.49 \pm 12.68$ & $36.44 \pm 18.72$ & 5.506 & 0.005 \\
\hline
\end{tabular}

Table 2: Comparison of CA-125 level in the completed and aborted cases in group $\mathrm{I}$ at $5^{\text {th }}$ and $\mathbf{1 0}^{\text {th }}$ week of gestation.

\begin{tabular}{|c|c|c|c|c|c|}
\hline \multirow{2}{*}{ Total no. $=\mathbf{5 0}$} & & \multirow{2}{*}{$\begin{array}{l}\text { Continued }(n=46) \\
\text { Mean } \pm \text { SD }\end{array}$} & \multirow{2}{*}{$\begin{array}{l}\text { Abortion }(n=4) \\
\text { Mean } \pm \text { SD }\end{array}$} & \multicolumn{2}{|c|}{ Independent t-test } \\
\hline & & & & $\mathbf{t}$ & P value \\
\hline \multirow{2}{*}{ CA125 (U/ml) } & At $5^{\text {th }}$ week & $13.44 \pm 6.28$ & $49.00 \pm 17.46$ & -9.113 & 0.000 \\
\hline & At $10^{\text {th }}$ week & $20.29 \pm 9.62$ & $68.37 \pm 35.53$ & -6.762 & 0.000 \\
\hline
\end{tabular}

It shows highly statistically significant difference between completed and aborted cases in group I at $5^{\text {th }}$ and $10^{\text {th }}$ week of gestation.

Table 3: Comparison of CA125 level in the completed and aborted cases in group IIa at $5^{\text {th }}$ and $\mathbf{1 0}^{\text {th }}$ week of gestation.

\begin{tabular}{|c|c|c|c|c|c|}
\hline \multirow{2}{*}{ Total no.=25 } & & \multirow{2}{*}{$\begin{array}{l}\text { Continued }(n=20) \\
\text { Mean } \pm \text { SD }\end{array}$} & \multirow{2}{*}{$\begin{array}{l}\text { Abortion }(n=5) \\
\text { Mean } \pm \text { SD }\end{array}$} & \multicolumn{2}{|c|}{ Independent $t$-test } \\
\hline & & & & t & $P$ value \\
\hline \multirow{2}{*}{ CA125 (U/ml) } & At $5^{\text {th }}$ week & $5.85 \pm 3.55$ & $43.68 \pm 45.71$ & -3.475 & 0.002 \\
\hline & At $10^{\text {th }}$ week & $11.69 \pm 6.86$ & $69.29 \pm 64.16$ & -3.771 & 0.001 \\
\hline
\end{tabular}

It shows highly statistically significant difference between completed and aborted cases in group IIa at 5th and 10th week of gestation.

Table 4: Sensitivity, specificity, PPV, NPV of CA-125 in group IIa at $5^{\text {th }}$ week of gestation.

\begin{tabular}{|lllllll|}
\hline Parameters & Criterion & AUC & Sensitivity & Specificity & +PV & -PV \\
\hline CA-125 at 5 $5^{\text {th }}$ week $(\mathbf{U} / \mathbf{m l})$ & $>38.25$ & 1.000 & 100.00 & 100.00 & 100.0 & 100 \\
\hline
\end{tabular}

At a cut-off value of CA125 (38.25 U/ml) the highest sensitivity and specificity values of $100.00 \%$ were obtained. 
Table 5: Sensitivity, specificity, PPV, NPV of CA125 in group IIa at $10^{\text {th }}$ week of gestation.

\begin{tabular}{|c|c|c|c|c|c|c|}
\hline Parameters & Criterion & $\mathbf{A U C}$ & Sensitivity & Specificity & $+\mathbf{P V}$ & $-\mathbf{P V}$ \\
\hline CA-125 at $10^{\text {th }}$ week $(\mathrm{U} / \mathrm{ml})$ & $>53$ & 1.000 & 100.00 & 100.00 & 100.0 & 100 \\
\hline
\end{tabular}

A cut-off value of $53 \mathrm{U} / \mathrm{ml} \mathrm{CA} 125$ gives sensitivity and specificity values of $100.00 \%$

Table 6: Comparison of CA-125 level in the completed and aborted cases in group IIb at $5^{\text {th }}$ and $10^{\text {th }}$ week of gestation.

\begin{tabular}{|c|c|c|c|c|c|}
\hline \multirow{2}{*}{ Total no. $=25$} & & \multirow{2}{*}{$\begin{array}{l}\text { Continued }(n=20) \\
\text { Mean } \pm \text { SD }\end{array}$} & \multirow{2}{*}{$\begin{array}{l}\text { Abortion }(\mathrm{n}=5) \\
\text { Mean } \pm \text { SD }\end{array}$} & \multicolumn{2}{|c|}{ Independent t-test } \\
\hline & & & & $\mathbf{t}$ & $P$ value \\
\hline \multirow[t]{2}{*}{ CA-125 (U/ml) } & At $5^{\text {th }}$ week & $14.07 \pm 10.24$ & $77.94 \pm 11.51$ & -12.198 & 0.000 \\
\hline & At $10^{\text {th }}$ week & $20.93 \pm 15.02$ & $113.95 \pm 21.23$ & -10.607 & 0.000 \\
\hline
\end{tabular}

It shows highly statistically significant difference between completed and aborted cases in group II b at $5^{\text {th }}$ and $10^{\text {th }}$ week of gestation.

Table 7: Sensitivity, specificity, PPV, NPV of CA-125 in group IIb at $5^{\text {th }}$ week of gestation.

\begin{tabular}{|lllllll|}
\hline Parameters & Criterion & AUC & Sensitivity & Specificity & +PV & -PV \\
\hline CA-125 at $5^{\text {th }}$ week $(\mathbf{U} / \mathbf{m l})$ & $>48.6$ & 0.923 & 75.00 & 100.00 & 100.0 & 89.5 \\
\hline
\end{tabular}

At a cut of value of CA-125 (48.6 U/ml) the sensitivity and specificity were $75.00 \%$ and $100.00 \%$.

Table 8: Sensitivity, specificity, PPV, NPV of CA-125 in group IIb at $10^{\text {th }}$ week of gestation.

\begin{tabular}{|lllll|ll|}
\hline Parameters & Criterion & AUC & Sensitivity & Specificity & +PV & -PV \\
\hline CA-125 at $\mathbf{1 0}^{\text {th }}$ week $(\mathbf{U} / \mathbf{m l})$ & $>68$ & 0.958 & 85.71 & 94.12 & 85.7 & 94.1 \\
\hline
\end{tabular}

CA-125, at a cut-off value $(68 \mathrm{U} / \mathrm{ml})$ the sensitivity and specificity were $85.71 \%$ and $94.12 \%$ respectively.

The results of the ROC curve analysis demonstrate the high prognostic value of CA-125 at $5^{\text {th }}$ week of gestation for pregnancy failure in group IIb with a cut-off value $(48.6 \mathrm{U} / \mathrm{ml})$ the highest sensitivity and specificity values of $100.00 \%$ were obtained (Table 6) and at $10^{\text {th }}$ week of gestation with a cut-off value of $68 \mathrm{U} / \mathrm{ml}$ the sensitivity and specificity were $85.71 \%$ and $94.12 \%$ respectively (Table 7).

\section{DISCUSSION}

In 2017 a study was done by Eid et al concluded that CA125 and progesterone are good predictors for the outcome me of $1^{\text {st }}$ trimester of pregnancy in both normal women and those with threatened abortion. Both have excellent specificity and good sensitivity in prediction of the outcome. $^{5}$

CA-125, $\beta$ HCG and progesterone are good biochemical markers and FHR and CRL are good ultrasonographic markers for the prediction of outcome in women with threatened abortion. FHR at $110 \mathrm{bpm}$ gives the best predictivity followed by serum $\mathrm{P}$ at $25 \mathrm{ng} / \mathrm{ml}, \beta \mathrm{HCG}$ at $19887 \mathrm{mIU} / \mathrm{ml}, \mathrm{CA}-125$ at $80 \mathrm{IU} / \mathrm{ml}$ and CRL at $21 \mathrm{~mm}$ with the least predictive accuracy among studied markers. Adding serum progesterone to FHR gave a sensitivity and specificity of $100 \%{ }^{6}$

At 2001 it was proved that CA-125 maternal serum level increases during early first trimester of pregnancy than that in nonpregnant women. ${ }^{7}$ And that this elevation is exaggerated in cases with threatening symptom to the extent that the patient who presented the highest level of the antigen did abort later. ${ }^{8}$

This was explained by the fact that CA-125 molecules are found in abundant quantities in cytosolic fraction of decidual cells. During early gestation, chorionic villi invade the decidual cells, also in case of abortion the decidual cell destruction leads to release of CA-125 molecules into the maternal blood stream. ${ }^{9}$

Therefore, measurement of maternal serum CA-125 in cases of threatened abortion could be useful to determine the extent of decidual destruction which is directly related to the eventual outcome of pregnancy.

In the present study the mean serum level for CA-125 in all studied cases was $(16.29 \pm 12.24) \mathrm{U} / \mathrm{ml}$ for group I at $5^{\text {th }}$ week of gestation and was $(23.23 \pm 16.58) \mathrm{U} / \mathrm{ml}$ at $10^{\text {th }}$ week of gestation. In group IIa the mean serum level for CA-125 was $(17.96 \pm 10.69) \mathrm{u} / \mathrm{ml}$ at $5^{\text {th }}$ week of gestation and was $(28.49 \pm 12.68) \mathrm{U} / \mathrm{ml}$ at the $10^{\text {th }}$ while in group IIb the mean serum level for CA-125 was $(26.84 \pm 18.02) \mathrm{U} / \mathrm{ml}$ at $5^{\text {th }}$ week of gestation and was $(36.44 \pm 18.72) \mathrm{U} / \mathrm{ml}$ at the $10^{\text {th }}$ week of gestation. Additionally, our study demonstrated that serum CA-125 level in the study group IIa and IIb was significantly higher than that in the control group as shown in Table 1. 
While, in group I the mean of CA-125 in the cases continued pregnancy was $(13.44 \pm 6.28 \mathrm{IU} / \mathrm{ml})$ and in cases ended by abortion was $(49.00 \pm 17.46)$ at $5^{\text {th }}$ week of gestaion and at $10^{\text {th }}$ week the mean was $(20.29 \pm 9.62$ $\mathrm{IU} / \mathrm{ml})$ and $(68.37 \pm 35.53)$ respectively shown in Table 2. In group IIa the mean of CA-125 in the cases continued pregnancy was $(5.85 \pm 3.55 \mathrm{IU} / \mathrm{ml})$ and in cases ended by abortion was $(43.68 \pm 45.71)$ at $5^{\text {th }}$ week of gestation while at $10^{\text {th }}$ week the mean was $(11.69 \pm 6.86 \mathrm{IU} / \mathrm{ml})$ and (69.29 \pm 64.16$)$ respectively shown in Table 3.

In the present study as regard group IIa with a cut of value of CA125 (>38.25 U/ml) and $(>53.00 \mathrm{U} / \mathrm{ml})$ at $5^{\text {th }}$ and $10^{\text {th }}$ week of gestation respectively, sensitivity and specificity were $100.00 \%$ as shown in Tables 4 and 5 .

As regards group IIb the mean of CA-125 in the cases continued pregnancy was $(14.07 \pm 10.24 \mathrm{IU} / \mathrm{ml})$ and in cases ended by abortion was $(77.94 \pm 11.51)$ at $5^{\text {th }}$ week of gestation while at $10^{\text {th }}$ week the mean was $(20.93 \pm 15.02$ $\mathrm{IU} / \mathrm{ml})$ and $(113.95 \pm 21.23)$ respectively shown in Table 6.

In group $\mathrm{IIb}$, at a cut of value $(>45.6 \mathrm{U} / \mathrm{ml})$ at $5^{\text {th }}$ week of gestation, sensitivity and specificity were $75.00 \%$ and $100.00 \%$ respectively. And at $10^{\text {th }}$ week of gestation with a cut of value of CA-125 (>68 U/ml), sensitivity and specificity were $85.71 \%$ as shown in Tables 7 and 8 .

This is in agreement with a study done by Mohamady et al 2016 as they reported that the use of certain maternal serum markers (CA-125 and progesterone) in the first trimester represent noninvasive, early and fast methods that can be considered as a good predictor for the outcome of pregnancy in cases with threatened abortion. ${ }^{10}$

They also reported that CA-125 level above $31.2 \mathrm{IU} / \mathrm{ml}$ predicted occurrence of miscarriage with an overall accuracy of $99.4 \%$. Similar to these results, Fiegler et al, in a study on 200 consecutive women with spotting, viable ultrasound picture of the embryo in the uterus and gestational age ranging from 4-12 weeks, found that CA125 levels were significantly higher in patient with threatened abortion $57.4 \pm 10.0 \mathrm{U} / \mathrm{ml}$ in comparison with control group $14.3 \pm 4.0 \mathrm{U} / \mathrm{ml}$ and also they were significantly elevated in pregnancies terminating eventually in spontaneous abortion $84.7 \pm 30.7 \mathrm{U} / \mathrm{ml}$ than those who continued $33.2 \pm 14.8 \mathrm{U} / \mathrm{ml}$ their pregnancies. ${ }^{11}$ They also mentioned that women with symptoms of imminent abortion who have a CA-125 level of $\geq 43.1$ $\mathrm{U} / \mathrm{ml}$ should be considered as having a greater risk of miscarriage and patients with bleeding of $\geq 3$ days should have a threshold value of $66.5 \mathrm{U} / \mathrm{ml}$ applied as a risk determinant. They concluded that a single serum CA-125 level determination is valuable in women with imminent abortion presenting with abdominal pain, vaginal bleeding or both.

Also in a similar study for Ghoneim et al in a study on 88 patients with threatened abortion in the first trimester classified into continued and non-continued group stated that the mean serum levels of CA-125 were (76.59 and $137.45 \mathrm{U} / \mathrm{ml}$ ) for both group respectively and were found to be significantly higher in non-continued group. ${ }^{12}$

The present study showed that a significantly higher CA125 levels in intrauterine pregnancies complicated by abortions compared normal intrauterine pregnancies, reinforcing the majority of previous similar studies done by Katsikis et al and Schmidt et al.,

And lastly Salem et al on their study on 60 patients with threatened abortion divided into continued and noncontinued groups reported that serum CA-125 were significantly higher in non-continued $(79.1 \mathrm{IU} / \mathrm{ml})$ than in continued group $(36.2 \mathrm{IU} / \mathrm{ml})$ and they concluded that a single serum measurement of CA-125 is an excellent positive test in cases of threatened first trimester miscarriage. ${ }^{13}$ However, the cut-off reported in this study is lower than that reported by Scarpellini et al and Ghoneim et al who considered a cut-off level of $120 \mathrm{U} / \mathrm{ml}^{.12,14}$

Azogui et al considered $125 \mathrm{U} / \mathrm{ml}$ as a cut-off level and it is significantly lower than that mentioned by Jerome et al, who considered a serum level of $150 \mathrm{U} / \mathrm{ml}$ as a cut-off level. ${ }^{15,16}$

This discrepancy between our cut off value and their cut off value was due to, they did not exclude the patients conceived by IVF (in vitro fertilization) from their study and also by the presence of high percentage of chromosomal abnormalities, confirmed by chromosomal studies of aborted fetuses.

There are many theories that explain the access of the decidual CA-125 to the maternal circulation, the most logic theory explaining the compartmental distribution of the CA-125 during pregnancy was presented by Ocer et al who stated that CA-125 molecules are found in abundant quantities in the cytosolic fraction of decidual cells. During early gestation, chorionic villi invade the decidual cells, while at term, mechanical disruption of decidual cells occurs at the time of placental separation. During these two events, decidual cells release the CA-125 molecules into maternal blood stream, explaining the two peaks of serum CA-125 in maternal circulation during the 1st trimester and immediately after labor and also with abortion. Otherwise, CA-125 molecules are preferentially secreted into the amniotic fluid. ${ }^{17}$

Our study showed that a measurement of serum CA-125 in a period between (5-10) weeks of gestation in patients suffering from vaginal spotting or bleeding is a good predictor of pregnancy outcome.

This study has some limitations. Causes of high CA-125 was only ruled out by history and examination however no documented baseline CA-125 was done for the pregnant ladies before pregnancy. Therefore, another study should consider preconceptional measuring of CA-125 level. 


\section{CONCLUSION}

In conclusion, the findings of this study suggest the possibility of using serum CA-125 alone for the prognosis of first trimesteric threatened abortion with cut-off value of CA-125 38.25 U/ml at $5^{\text {th }}$ week of gestation and $53 \mathrm{U} / \mathrm{ml}$ at $10^{\text {th }}$ week of gestation in patients presented with pain only but in patients presented with minimal vaginal bleeding a cut-off value of CA-125 at $5^{\text {th }}$ week of gestation become $45.6 \mathrm{U} / \mathrm{ml}$ and $68 \mathrm{U} / \mathrm{ml}$ at $10^{\text {th }}$ week of gestation.

CA-125 alone can discriminate between continued and non continued pregnancy especially if repeated at $5^{\text {th }}$ and $10^{\text {th }}$ week of gestation.

\section{ACKNOWLEDGMENTS}

I'd like to express my respectful thanks and profound gratitude to the whole team of doctors, nurses and laboratory technicians in Al-Azhar University Faculty of Medicine for Girls. I would also like to express my sincere appreciation and gratitude to the patients and pregnant women who was committed and supportive throughout this work.

\section{Funding: No funding sources}

Conflict of interest: None declared

Ethical approval: The study was approved by the Institutional Ethics Committee of Al Azhar University

\section{REFERENCES}

1. Katsikis I, Rousso D, Farmakiotis D, Kourtis A, Kandarakis E, Panidis D. Receiver operator characteristics and diagnostic value of progesterone and CA-125 in the prediction of ectopic and abortive intrauterine gestations. Eur J Obstet Gynecol Reprod Biol. 2006;125:226-32.

2. Madendag Y, Col-Madendag I, Kanant-Pekas M, Danisman N. Predictive power of serum CA-125 and LDH in the outcome of first trimester pregnancies with human chronic gonadotropin levels below discriminatory zone. Arch Gynecol Obstet. 2009;279(5):826-30.

3. Schmidt T, Rein DT, Foth D, Eibach H, Kurbacher C, Mallmann P, et al. Prognostic value of repeated serum CA 125 measurements in first trimester pregnancy. Eur J Obstet Gynecol Reprod Biol. 2001;97(2):16873.

4. Yadav K, Ojha P, Chopra A. Comparison of maternal serum CA-125 and ultrasonography findings as a prognostic marker in threatened abortion. Int J Reprod Contracept Obstet Gynecol. 2021;10:2253-8.

5. Eid M, Abdallah AK. Cancer antigen 125 (CA-125) and serum progesterone as predictors of fate of threatened abortion: case control study. Int J Fertil Steril. 2017;7(4).

6. Maged AM, Mostafa WA. Biochemical and ultrasonographic predictors of outcome in threatened abortion. Middle East Fertil Soc J. 2013;18(3):17781.

7. Bon GG, Kenemans P, Verstraeten AA, Go S, Philipi PA, Van Kamp GJ, et al. Maternal serum Ca125 and Ca15-3 antigen levels in normal and pathological pregnancy. Fet Diagn Therap. 2001;16(3):166-72.

8. Kaminski K, Korczala KZ, Fiegler P. Level of CA125 antigen in serum of first trimester normal and miscarried pregnancy. Wiad Lek. 2002;55(5-6):3104.

9. Foth D, Romer T. Maternal CA-125 serum level in intrauterine pregnancy and abortion in the first trimester. Zentralbl Gynakol. 2000;122(4):217-21.

10. Mohamady MA, Fattah GA, Elkattan E, Byoumy R, Hamed DA. Correlation of serum CA-125 and progesterone levels with ultrasound markers in the prediction of pregnancy outcome in threatened miscarriage. Int J Fertil Steril. 2016;9(4):506-11.

11. Fiegler P, Katz M, Kaminski K, Rudol G. Clinical value of a single serum CA-125 level in women with symptoms of imminent abortion during the first trimester of pregnancy. Reprod Med. 2003;48(12):982-8.

12. Ghoneim MR, El-Shahat AM, El-Essawy LY. Maternal serum CA 125 in first trimester threatened abortion. Ain Shams Medical J. 2005;56(1,2,3):24757

13. Salem MR, Hassan FR, Abd El Maqsud KA. The value of maternal serum $\beta$-HCG and CA 125 Levels with trans-vaginal color Doppler of the uterine arteries in assessment of cases of first trimesteric threatened abortion. Cairo University. 2005;167

14. Scarpellini F, Mastrone M, Sbracia M, Scarpellini L. Serum CA-125 and first trimester abortion. Int J Gynaecol Obstet. 1995;49:259-64.

15. Azougi G, Yaronovski A, Zohar S, Ben-Shlomo I. CA-125 is elevated in viable pregnancies destined to be miscarried: a prospective longitudinal study. Fertil Steril. 1996;65(5):1059-61.

16. Check JH, Nowroozi K, Winkel CA, Johnson T, Seefried L. Serum CA125 level in early pregnancy and subsequent spontaneous abortion. Obstet Gynecol. 1990;75:742-4.

17. Ocer F, Bese T, Saridogan E, Aydinli K, Atasu T. The prognostic significance of maternal serum CA-125 measurement in threatened abortion. Eur J Obstet Gynecol Reprod Biol. 1992;46:137-42.

Cite this article as: Badr NS, El Mallah SY, El Mahdy MI, Ahmad HF. Maternal serum CA-125 repeated measurement during pregnancy and how to use as a prognostic factor of first trimester pregnancy outcome. Int J Reprod Contracept Obstet Gynecol 2022;11:1-6. 